\title{
BIOMETRIC TRAITS AND VARIABILITY OF HONEY BEES FROM JABLANICA DISTRICT
}

\author{
M. Mladenovići ${ }^{\text {, V. Pešev }}{ }^{2}$ \\ ${ }^{1}$ Faculty of Agriculture, 11080, Belgrade-Zemun, Republic of Serbia \\ ${ }^{2}$ Faculty of Agriculture, 38219, Lešak, Republic of Serbia \\ Corresponding author: valentinavh@neobee.net \\ Original scientific paper
}

Abstract: Morphometric parameters are used in order to study taxonomy, systematization, and to determine the race of honey bees. Large number of morphological parameters is studied both worldwide and in our country, so the honey bee has become the most studied insect with about 42 morphometrics, quantitative traits. In this paper, following biometric traits were identified: tongue length, front wing length, front wing width, cubital index, length and width of the third tergit, length and width of wax plate mirror, femur length, tibia length, length and width of basitarsus and the tarsal index. Samples of bees included in these studies were taken from the site Slavujevac, Strojkovce and Leskovac from honey bee colonies of good health condition and raised under the influence of natural selection. Based on the statistical and descriptive statistics methods, the total variability and variation coefficient for all individuals studied honey bee races were determined.

Key words: honey bees, biometrics, Jablanica District

\section{Introduction}

In different areas of the world, under the influence of various environmental factors and during the evolutionary development of honey bees, different races with specific biometric traits appeared. These specific morphometric traits are used in their identification and classification. The first studied biometric traits were the size and color. In the last decades, many researches of honey bee potential were conducted in our country, from the aspect of morphometric parameters, Stojanović (1992), Georgijev (2001), Stevanović (2002), Georgijev (2006), Jevtić (2007), Nedić (2009), etc.. When it comes to Carniolan honey bee, Ruttner (1988) was among first to report that trough precise morphometric studies more ecotypes may be identified within the race. The specificity of the relief and eco-climatic conditions on the territory of Serbia influences the diversity and variability of honey bee. The influence of environment on body size was demonstrated in experiments conducted by Alpatlov (1929). 
The aim of this study was to determine the variability of honey bees from Jablanica district within the certain taxon on morphological and micromorphological level.

\section{Materials and Methods}

Determination of morphometric traits was performed on the samples from the area of southern Serbia from the sites Slavujevac, Strojkovce and Leskovac. Samples consisted of 10 bees. Sampled honey bees were of indigenous origin. After sampling, the bees were kept in $96 \%$ alcohol and kept in a refrigerator at a temperature of $+4^{\circ} \mathrm{C}$ until measurement. Morphometric measurements of angles were made by standard methods of Ruttner et al., (1978). For the measurements process, temporary anatomical preparations were made. Using tweezers, certain body parts of bees were removed, taped to the foil and than scanned with a resolution of $9600 \mathrm{dpi}$, and then measured using the computer program and Corel Draw 11.

\section{Results and Discussion}

Table 1 shows the values of morphometric parameters and the length and width of the front right wing, the values of $a$ and $b$ of the third cubital cell and the values of the cubital index.

Table 1. Morphometric traits of the front wing

\begin{tabular}{|l|c|c|c|c|c|}
\hline \multirow{2}{*}{ Morphometric traits } & \multicolumn{5}{c|}{ Wings } \\
\cline { 2 - 7 } & $\begin{array}{c}\text { Length } \\
(\mathrm{mm})\end{array}$ & $\begin{array}{c}\text { Width } \\
(\mathrm{mm})\end{array}$ & $\mathrm{A}$ & $\mathrm{B}$ & CI \\
\hline \multicolumn{7}{|c|}{ SLAVUJEVCE } \\
\hline average & 9.00 & 3.11 & 0.57 & 0.25 & 2.34 \\
\hline $\max$ & 9.40 & 3.22 & 0.66 & 0.30 & 3.00 \\
\hline min & 8.46 & 3.03 & 0.48 & 0.21 & 1.61 \\
\hline CV (\%) & 2.21 & 2.02 & 9.50 & 13.19 & 14.55 \\
\hline \multicolumn{7}{|c|}{} \\
\hline average & 9.10 & 3.14 & 0.58 & 0.26 & 2.26 \\
\hline max & 9.24 & 3.24 & 0.63 & 0.31 & 2.65 \\
\hline min & 8.95 & 3.02 & 0.51 & 0.21 & 2.89 \\
\hline CV (\%) & 1.10 & 2.12 & 6.41 & 10.98 & 14.55 \\
\hline \multicolumn{7}{|c|}{} \\
\hline average & 9.02 & 3.13 & 0.59 & 0.15 & 1.83 \\
\hline max & 9.37 & 3.20 & 0.69 & 0.25 & 3.49 \\
\hline min & 8.73 & 3.08 & 0.49 & 0.28 & 1.83 \\
\hline CV (\%) & 2.00 & 1.33 & 17.43 & 10.26 & 20.01 \\
\hline Average Morphometric traits & 9.04 & 3.13 & 0.58 & 0.25 & 2.41 \\
\hline Average CV (\%) & 1.77 & 1.82 & 11.11 & 11.48 & 18.39 \\
\hline
\end{tabular}

Length of cubital nerve „A” (CUBA): 2-4;

Length of cubital nerve „B” (CUBB): 1-2; 
The determined values for the length of front right wing, average for studied sites, ranged from 9.00 to $9.10 \mathrm{~mm}$ with average variation coefficient of $1.77 \%$. Krivcov (1992) points out that the wing length of Carniolan honey bee ranges from 9.00 to $9.42 \mathrm{~mm}$ which corresponds with the values obtained in our study. Stojanović (1992) in her researches on the bees from Sjenica had obtained values of 9.42 to $9.53 \mathrm{~mm}$ and those values do not correspond with our research. Krivcov (1992) stated for that the average front wing width in Carniolan honey bee ranges in the interval of variation of 3.13-3.29 $\mathrm{mm}$. The average value of the front right wing width in the samples from all three sites was $3.13 \mathrm{~mm}$.

Cubital index shows the purity of race and by using it the influence of other races can be determined. It represents the ratio of A and B of the third cubital cell on the front wing of the worker bees. The average value of the cubital index was 2.41. Georgiev (2001) was examining bees Timok region from 7 sites, and determined the value of cubital in the range of 2.47-2.66.

Table 2. Morphometric characteristics of tongue, tergit and wax mirror

\begin{tabular}{|l|c|c|c|c|c|}
\hline \multirow{2}{*}{ Morphometric traits } & Tounge & \multicolumn{2}{c|}{ Tergit } & \multicolumn{2}{c|}{ Wax minor } \\
\cline { 2 - 6 } & $\begin{array}{c}\text { Length } \\
(\mathrm{mm})\end{array}$ & $\begin{array}{c}\text { Length } \\
(\mathrm{mm})\end{array}$ & $\begin{array}{c}\text { Width } \\
(\mathrm{mm})\end{array}$ & $\begin{array}{c}\text { Length } \\
(\mathrm{mm})\end{array}$ & $\begin{array}{c}\text { Width } \\
(\mathrm{mm})\end{array}$ \\
\hline \multicolumn{7}{|c|}{ SLAVUJEVCE } \\
\hline average & 6.44 & 2.18 & 4.29 & 2.53 & 1.48 \\
\hline max & 6.86 & 2.28 & 4.57 & 2.76 & 1.58 \\
\hline min & 6.05 & 2.09 & 3.72 & 2.20 & 1.45 \\
\hline CV (\%) & 4.05 & 2.77 & 6.80 & 6.72 & 2.77 \\
\hline \multicolumn{7}{|c|}{ STROJKOVCE } \\
\hline average & 6.69 & 2.17 & 4.56 & 2.41 & 1.45 \\
\hline max & 7.36 & 2.30 & 4.96 & 2.69 & 1.57 \\
\hline min & 6.33 & 2.07 & 4.17 & 2.22 & 1.25 \\
\hline CV (\%) & 4.86 & 3.62 & 5.58 & 5.61 & 7.16 \\
\hline \multicolumn{7}{|c|}{ LESOVAC } & & & \\
\hline average & 6.37 & 2.14 & 4.55 & 2.47 & 1.50 \\
\hline max & 6.77 & 2.32 & 4.82 & 2.59 & 1.64 \\
\hline min & 5.90 & 2.01 & 4.46 & 2.36 & 1.30 \\
\hline CV (\%) & 4.24 & 4.93 & 2.29 & 2.65 & 6.24 \\
\hline ABerage Morphometric traits & 6.50 & 2.17 & 4.47 & 2.47 & 1.47 \\
\hline Average CV (\%) & 4.38 & 3.77 & 4.89 & 4.99 & 5.39 \\
\hline
\end{tabular}

Tongue length had an average value of $6.5 \mathrm{~mm}$. The minimum average value was determined in the site Leskovac and was $6.37 \mathrm{~mm}$ and the highest recorded value was in site Strojkovce $(6.69 \mathrm{~mm})$. In researches of Krivcov and Lebedev (1995) tongue length in carnica ranges from 6.3-6.9 mm. According to some authors can be up to $8.2 \mathrm{~mm}$, Konstantinovic (1966). 
The average tergit length ranged from $2.17 \mathrm{~mm}$. The obtained data are similar to data provided by Plužnikov (1994) for this parameter, obtained by examining the bees from Bosnia and Herzegovina $(2.17 \mathrm{~mm})$, Montenegro $(2.20$ $\mathrm{mm})$ and Serbia $(2.32 \mathrm{~mm})$. Somewhat higher value was noted in the research of biometric traits conducted by Georgiev (2001) in which the bees from Timok region had values for this trait in range from $2.19-2.28 \mathrm{~mm}$.

The average value of sampled bees from all three sites for the width of the third tergit was $4.47 \mathrm{~mm}$. In the researches of bees from Timok region by Georgijev (2006) it is stated that the width of the third tergit ranged from 4.23 to $4.87 \mathrm{~mm}$.

The average length and width of wax mirrors were $2.47 \mathrm{~mm}$ and $1.47 \mathrm{~mm}$ respectively.

Variation coefficient for the tongue length, in the monitored sites, was 4.38 $\%$, for the length and width of tergit were 3.77 and $4.89 \%$, and for the length and width of the wax mirrors were $4.99 \%$ and $5.39 \%$.

Table 3. Morphological characteristics of the hing leg

\begin{tabular}{|l|c|c|c|c|c|}
\hline \multirow{2}{*}{ Morphometric traits } & \multicolumn{5}{|c|}{ Hind leg (mm) } \\
\cline { 2 - 6 } & $\begin{array}{c}\text { Femur } \\
\text { length } \\
(\mathrm{mm})\end{array}$ & $\begin{array}{c}\text { Tibie } \\
\text { length } \\
(\mathrm{mm})\end{array}$ & $\begin{array}{c}\text { Basitarsus } \\
\text { length } \\
(\mathrm{mm})\end{array}$ & $\begin{array}{c}\text { Basitarsus } \\
\text { width } \\
(\mathrm{mm})\end{array}$ & $\begin{array}{c}\text { Tarsal } \\
\text { index }\end{array}$ \\
\hline \multicolumn{5}{|c|}{ SLAVUJEVCE } \\
\hline average & 3.21 & 2.97 & 1.89 & 1.21 & 1.57 \\
\hline max & 3.42 & 3.09 & 2.09 & 1.31 & 1.95 \\
\hline min & 3.07 & 2.88 & 1.77 & 1.05 & 1.31 \\
\hline CV (\%) & 4.10 & 2.80 & 6.78 & 5.83 & 12.11 \\
\hline \multicolumn{7}{|c|}{ STROJKOVCE } \\
\hline average & 3.12 & 3.04 & 2.08 & 1.23 & 1.70 \\
\hline max & 3.43 & 3.39 & 2.19 & 1.36 & 1.87 \\
\hline min & 2.25 & 2.76 & 1.96 & 1.14 & 1.44 \\
\hline CV (\%) & 10.38 & 6.12 & 3.64 & 4.75 & 6.25 \\
\hline \multicolumn{7}{|c|}{ LESKOVAC } \\
\hline average & 3.06 & 2.97 & 1.98 & 1.14 & 1.73 \\
\hline max & 3.26 & 3.23 & 2.28 & 1.24 & 1.99 \\
\hline min & 2.54 & 2.71 & 1.67 & 1.03 & 1.54 \\
\hline CV (\%) & 6.63 & 5.16 & 9.77 & 5.59 & 8.86 \\
\hline Average Morphometric traits & 3.13 & 2.99 & 1.98 & 1.19 & 1.66 \\
\hline Average CV (\%) & 7.04 & 4.69 & 6.73 & 5.39 & 6.67 \\
\hline
\end{tabular}

Average values the femur length were $3.13 \mathrm{~mm}$. The average tibia length was $2.99 \mathrm{~mm}$, or by sites, Slavujevce $2.97 \mathrm{~mm}$ at Strojkovce $3.04 \mathrm{~mm}$ and Leskovac $2.97 \mathrm{~mm}$. Length and width of basitarsus had average values of 1.98 and $1.19 \mathrm{~mm}$, respectively, while tarsal index had an average value of 1.66 . Variation coefficients, by the traits, show the following average values: femur length $7.04 \%$, tibia length $4.69 \%$, basitarsus length 6.73 , basitarsus width 5.39 and tarsal index $6.67 \%$. 


\title{
Conclusion
}

From the results of descriptive statistics for each individual character between sites can be concluded that there is great variability in the tested honey bee samples from Jablanica District. The lowest variability was observed in wing length and the highest variability was determined in the cubital index. The values of morphometric parameters are consistent with the values of morphometric parameters for Carniolan honey bee (Apis mellifera carnica Poll.).

The results of the research will help in further studies and further selection as well as conservation of indigenous material of honey bee Apis mellifera carnica Poll. from the area of Jablanica District.

\section{Acknowledgment}

Research was financed by the Ministry of Education and Science, Republic of Serbia, project TR 46009.

\section{Biometrijske osobine i varijabilnost kod medonosne pčele iz Jablaničkog okruga}

\author{
M. Mladenović, V. Pešev
}

\section{Rezime}

U cilju proučavanja taksonomije, sistematizacije i utvrdjivanja rasne pripadnosti medonosne pčele koriste se morfometrijski parametri. Zahvaljujući mnogim istraživanjima došlo se do većeg broja morfoloških pokazatelja koji se ispituju kako u svetu tako i kod nas, tako da je medonosna pčela postala najproučeniji insekat sa ukupno sa oko 42 morfometrijskih, kvantitativnih obeležja.

U radu su utvrđeni biometrijski parametri i to: dužina jezika, dužina prednjeg krila, širina prednjeg krila, kubitalni indeks, dužina i širina trećeg tergita, dužina i širina voskovog ogledalca, dužina femura, dužina tibie, dužina i širina bazitarzusa i tarzalni indeks.

Uzorci pčela obuhvaćeni istraživanjima uzeti su sa lokaliteta Slavujevce, Strojkovce i Leskovac od pčelnjih društava koja su bila u dobroj zdravstvenoj kondiciji i odgajala su se pod uticajem prirodne selekcije.

Metodom deskriptivne statistike utvrdjena je ukupna varijabilnost, kao i koeficient varijacije za sve individue ispitane rase pčela. 


\section{References}

ALPATOV W.W. (1929): Biometrical studies on variacion an racus of the honey bee Apis mellifera L. Quart.Rev. Biol., 4, 1-57.

GEORGIJEV A. (2001): Biometrijske karekteristike medonosne pčele (Apis mellifera carnica Pollmann) Timočkog regiona. Specijalistički rad. Univerzitet u Beogradu, Poljoprivredni fakultet, 1-120.

GEORGIJEV A. (2006): Biološko-produktivne osobine medonosne pčele u istočnoj Srbiji. Magistarski rad, Univrezitet u Beogradu, Poljoprivredni fakultet, 1149.

KONSTANTINOVIĆ B. (1966): Addition to the study of morphologic and biologic traits of honey bee (Apis mellifera L.) from south-west Serbia. Yugoslavian Beekeeping, 9-11, 158-161.

KRIVCOV N.I. (1992): Kranjska rasa pčela. Preveo i priredio R. Živadinović, Pčelar, Beograd, jun 2004, 261.

КРИВЦОВ Н.И., ЛЕБЕДОВ В.И. (1995): Содржание пчелних семе с основама селекци и. Изд. ,, Колос“ Кишенев, Република Молдова.

JEVTIĆ G. (2007): Varijabilnost ekotipova medonosne pčele (Apis mellifera carnica Poll.) I njihov značaj u oprašivanju lucerke. Doktorska disertacija, Univerzitet u Beogradu, Poljoprivredni fakultet, 1-139.

NEDIĆ N. (2009): Biološko-proizvodne osobine medonosne pčele Apis mellifera carnica Poll.na teritoriji Srbije. Doktorska disertacija, Univerzitet u Beogradu, Poljoprivredni fakultet, 1-149.

PLUŽNIKOV L. (1994): Характеристика морфологических и хозаиствених признаков пчел Јогослабии. Докторска дисертација, Кишинев, Молдова.

RUTTNER F., TASSENCOVET L., LOVEAUX J. (1978): Biometrical-statistical analyzis of the geographic variability of Apis mellifera L. Apidiologie, 9, 363-381. RUTTNER F. (1988): Biogeography and taxonomy of honey bees. SpringerVerlag, New York.

STEVANOVIĆ J. (2002): Istraživanja morfometrijske i hromozomske varijabilnosti u funkciji očuvanja diverziteta keanjske medonosne pčele (Apis mellifera carnica Pollman, 1879) na teritoriji Srbije. Magistarska teza, Veterinarski fakultet u Beogradu, 1-190.

STOJANOVIĆ R. (1992): Izučavanje biometrijskih karekteristika elemnata spoljašnje morfologije medonosne pčele (Apis mellifca L.) sa različitih geografskih područja naše zemlje. Magistarska teza, Veterinarski fakultet, 1-100.

Received 30 June 2011; accepted for publication 15 August 2011 